\title{
Russia's Involvement in the Kosovo Case: Defending Serbian Interests or Securing its Own Influence in Europe?
}

\begin{abstract}
This article examines Russia's involvement in the Kosovo question. It shows that the Russian leadership has generally favored the Serbian authorities, but more importantly for its own influence, that it felt the urge to oppose the 1999 NATO intervention and the post-interventionist Western rhetoric. The argument that Russia has been primarily concerned with strengthening of its own position and that the involvement in the Kosovo question was expected to serve such an ambition can also be better understood by looking at some recent discrepancies. Namely, the fact that Russia has strongly insisted on the principle of territorial integrity in the case of Serbia, but then completely ignored it in the case of Ukraine, shows that its loud advocacy of Serbian territorial integrity was just a strategic instrument to matter in European official debates, especially when the post-1999 discussions about the Kosovo final status took place.
\end{abstract}

Keywords: Russia, Kosovo, Serbia, NATO intervention, European Union.

\section{Introduction}

Following the collapse of the Soviet Union in late 1991, the newly established Russian Federation was arguably preoccupied with its own economic and political consolidation as well as its regional and global identity, all being of crucial relevance for foreign policy choices. ${ }^{1}$ Aware of the three possible arrangements for Europe in the 1990s - one Europe (offering a pan-European economic, political and security system), European Union-Russian balance (with the understanding that the former Warsaw Pact states would seek membership in the EU at some point), and the new project for US hegemony (largely corresponding to NATO's expansion and, in fact, inclusion of the former Warsaw Pact states among its members), ${ }^{2}$ Russia needed a substantial external engagement. The fact that the North Atlantic Alliance was clearly interested in the former Warsaw Pact states contributed to an increase of antagonism between Moscow and NATO; in the Kremlin, the idea that the former Soviet satellite states of Central and Eastern Europe decided to change their position and go as far as to side militarily with the West "understandably exasperated Russians of all political colors." ${ }^{3}$ As it turned out, in addition to following the developments in the so-called

\footnotetext{
${ }^{1}$ See, for example, Robert H. Donaldson, Joseph L. Nogee and Vidya Nadkarni, The Foreign Policy of Russia: Changing Systems, Enduring Interests (New York: Routledge, 2014), and Douglas Lemke, "Great Powers in the Post-Cold War World: A Power Transition Perspective," in Balance of Power: Theory and Practice in the $21^{\text {st }}$ Century, eds. T. V. Paul, James J. Wirtz and Michel Fortmann (Stanford: Stanford University Press, 2004), 52-75.

${ }^{2}$ For more details on these arrangements, see Peter Gowan, “The Euro-Atlantic Origins of NATO's Attack on Yugoslavia," in Masters of the Universe? NATO's Balkan Crusade, ed. Tariq Ali (London: Verso, 2000), 3-45.

${ }^{3}$ Gilbert Achcar, "Rasputin Plays at Chess: How the West Blundered into a New Cold War," in Masters of the Universe? NATO's Balkan Crusade, ed. Tariq Ali (London: Verso, 2000), 57-98: 57. Still, it is important to note that the new Russian elite did not immediately question prospective NATO expansion into East Central Europe. However, by autumn 1993, this position had already started to change, with some officials perceiving NATO expansion as a plot against the Russian state. See Aurel Braun, "Russian Policy towards Central Europe and the Balkans," in The Foreign Policy of the Russian Federation, eds. Roger E. Kanet and Alexander V. Kozhemiakin (Basingstoke: Palgrave, 1997), 49-77.
} 
'near abroad' (because of substantial Russian minorities inhabiting some of the postSoviet states), ${ }^{4}$ the Moscow administration decided to pay close attention to the situation in the Balkans.

In the Yugoslav case, aware of its past relationship with the Serbian people and in contrast to European Community officials (apart from Greek), Russian representatives did attend the ceremony proclaiming the Federal Republic of Yugoslavia (FRY), a new state established by Serbia and Montenegro, in 1992. ${ }^{5}$ Such a decision reflected what Yuliy Vorontsov, Russian representative to the UN, would describe as Russia's overall ambition - "to strengthen the traditional links of friendship and cooperation with the Yugoslav peoples, to restore peace to their land and to guarantee their freedom and independence." 6 With the outbreak of conflict in Bosnia and Herzegovina, the Russian authorities kept condemning the fighting, warning the parties of its possible escalation, and advocating punishment of the responsible. ${ }^{7}$ In addition, within the Contact Group, established in 1994 to deal with the war in Bosnia and Herzegovina, Russian representatives strongly opposed the intentions of their Western colleagues (from France, Germany, the United Kingdom and the United States). They were "opposed to any use of force against the Serbs, fearing repercussions at home among nationalist politicians," who kept criticizing President Boris Yeltsin for "kowtowing to the West rather than coming to the aid of Serbs, with whom Russians share the Orthodox religion and a Slavic heritage." 8 As assessed in the literature, supporting the Serbian side during the Yugoslav crisis and often rejecting Western foreign policy initiatives was not an easy task, especially when it turned out that many provocations and violent acts were actually products of the regime of Slobodan Milošević. ${ }^{9}$ One author argues that Russia's confrontational position in the Balkans made some other policy choices, in fact, more probable. Its decision not to accuse the Serbs of their wrongdoings, indeed helped solidify the decision to pursue the NATO-led military intervention; still, this does not mean that a different approach might have prevented it, but it might have made the Serbs aware of their unfavorable position and forced them to give up sooner. ${ }^{10}$

\footnotetext{
${ }^{4}$ Peter Shearman, "Defining the National Interest: Russian Foreign Policy and Domestic Politics," in Kanet and Kozhemiakin, 1-27. In addition, see Alexei Arbatov, "Russia's Foreign Policy Alternatives," International Security 18, no. 2 (1993): 5-43, and Alex Pravda, "The Politics of Foreign Policy," in Developments in Russian and Post-Soviet Politics, eds. Stephen White, Alex Pravda and Zvi Gitelman (London: Palgrave, 1994), 208-36.

${ }^{5}$ See Daniel Bethlehem and Marc Weller (eds), The Yugoslav Crisis in International Law (Cambridge: Cambridge University Press, 1997), xxxv.

${ }^{6}$ United Nations Security Council, "Security Council Provisional Verbatim Record," 30 May 1992 (S/PV.3082). Still, as concluded in the literature assessing the first half of the 1990s, "securing Russia's influence in the Balkans had been subordinated to the larger aim of establishing cooperative relations with the western democracies" (Derek Averre, "From Pristina to Tskhinvali: The Legacy of Operation Allied Force in Russia's Relations with the West," International Affairs 85, no. 3 (2009): 575-91, 577).

${ }^{7}$ They stressed that "Russia ha[d] pursued an unwavering course of putting an end to war crimes and cannot remain indifferent to the flagrant mass violations of international humanitarian law in the territory of the former Yugoslavia. Murder, rape and 'ethnic cleansing' must cease immediately, and the guilty - whatever their affiliation - must be duly punished" (United Nations Security Council, "Security Council Provisional Verbatim Record," 22 February 1993, S/PV.3175).

${ }^{8}$ Carol J. Williams, "Balkans: The Mediators Differ in their Approach Following Serbs' Rejection of Last-Chance Peace Deal," Los Angeles Times, 30 July 1994.

${ }^{9}$ Braun, "Russian Policy," 62. See also Donaldson et al., The Foreign Policy of Russia, 245-9, and Jeffrey Mankoff, Russian Foreign Policy: The Return of Great Power Politics (Lanham, MD: Rowman \& Littlefield, 2009), 19-20.

${ }^{10}$ Christian Torun, Explaining Change in Russian Foreign Policy: The Role of Ideas in Post-Soviet
} 
The Kosovo question secured more international attention after the signature of the 1995 Dayton Agreement, bringing the war in Bosnia and Herzegovina to an end and, very important for the subsequent discussions about the Kosovo case, clearly insisting on the notion of territorial integrity. The dominant view in Russia was that Kosovo had to be approached as a Serbian internal issue and therefore Serbian sovereignty was not supposed to be challenged - an approach going hand in hand with Russia's domestic secessionist concerns, mainly in Chechnya. ${ }^{11}$ Still, the international decision to leave the Kosovo question unaddressed in the mid-1990s represented an opportunity for the militarist Kosovo Liberation Army (KLA) to criticize and ignore a pacifist doctrine of the Democratic League of Kosovo, established by a group of Albanian intellectuals in 1989 to protect Kosovo Albanian interests across the Yugoslav federation. ${ }^{12}$ As it happened to be the case, the escalation of confrontations between the local Serbs and Albanians in Kosovo was accompanied by a series of events in which the standpoint and expectations of the Russian side could not be ignored by its Western counterparts, even though it eventually turned out that "Russia's diplomacy during the [1999] war was as fruitless as were its efforts to prevent NATO's assault." ${ }^{13}$ However, after the war, as assessed by Oleg Levitin in 2000, who was directly involved in Moscow's Balkan policies throughout the 1990s, Kosovo became "closely intertwined with issues that are vital to Moscow - issues of European security and relations with the West," implying that it would stay on Russian foreign policy agenda in years to come. ${ }^{14}$

While the abundance of scholarly examinations of the Kosovo case have rightly focused on the overall context, the legality and possible consequences of the 1999 NATO involvement, the post-interventionist local and international positions, Kosovo's proclamation of independence and its recognition, and, finally, Kosovo's capacity to pursue necessary reforms in order to become a viable state - the question of how some of the involved players approached the Kosovo crisis as a possible way of strengthening their own influence on a broader scale has remained largely ignored. Accordingly, this article looks at the official Russian rhetoric and the country's overall position during and after the 1999 Kosovo crisis. It shows that the Russian leadership generally favored the Serbian authorities and their often-disputed policies (as it did throughout the whole decade preceding the Kosovo crisis), but more importantly for its own relevance, that it felt the urge to contradict the NATO intervention and the post-interventionist Western discourse and policy choices. By doing so, the presence as well as influence of Russia increased. Moreover, the obvious fatigue faced by the Brussels administration - to come up with a common EU position regarding the Kosovo status (due to the ever-popular secessionist debates within some of its member states, even though they did not object to the previous NATO action, such as Spain) - has represented an additional incentive for the Russian leadership to insist on rightness of its own uncompromised view and thus to reinforce its place in European affairs. The argument that Russia has been primarily concerned with strengthening of its own position and that the involvement in the

\footnotetext{
Russia's Conduct towards the West (Basingstoke: Palgrave, 2009), 109-10.

${ }^{11}$ James Hughes, "Russia and the Secession of Kosovo: Power, Norms and the Failure of

Multilateralism," Europe-Asia Studies 65, no. 5 (2013): 992-1016, 998.

${ }^{12}$ For a detail account of the KLA and its position vis-à-vis other groups and people, see David L.

Phillips, Liberating Kosovo: Coercive Diplomacy and US Intervention (Cambridge, MA: The MIT

Press, 2012), esp. chapter 5.

${ }^{13}$ Donaldson et al., The Foreign Policy of Russia, 273.

${ }^{14}$ Oleg Levitin, “Inside Moscow's Kosovo Muddle,” Survival 42, no. 1 (2000): 130-40, 131.
} 
Kosovo question was expected to serve such an ambition can be even better understood by looking at some recent discrepancies characterizing the official Russian stance when confronted with the principle of territorial integrity. Namely, the fact that Russia has strongly insisted on the principle of territorial integrity in the case of Serbia (so that Kosovo would remain its constituent unit), but then completely ignored such a sensitive principle in the case of Ukraine, in 2014, when it not only supported its disintegration but also annexed Crimea, suggests that Russia's loud advocacy of territorial integrity was largely an instrument, which helped it matter in European official debates, especially when the discussions about the Kosovo final status started to take place.

\section{Russia and the 1999 NATO Involvement in the FRY}

The UN Security Council resolution 1160, adopted in March 1998, stipulated that "the principles for a solution of the Kosovo problem should be based on the territorial integrity of the Federal Republic of Yugoslavia." ${ }^{15}$ In June, President Slobodan Milošević travelled to Moscow, where he sought additional support from Yeltsin. Some Priština-based media reported that the Serbian leader wanted Russian support "based on the principle of ignoring the Albanians" and "that Russia has given him such support, because Yeltsin and Milošević would not have signed a document which decides about the destiny of the third, that is, which gratifies the wishes of only one party. But such an approach to the problem of Kosovo is not realistic." ${ }^{16}$ Later, the Russian Duma called for a peaceful solution to the Kosovo crisis. It stressed that "Russian politicians have been very vocal in their support for the Serbs in Kosovo territory," but also outlined their concerns that "the threat of airstrikes is not over yet," warning the West that in case they should happen, "NATO will start its own Chechen war." 17 With all this in mind, it is possible to argue that by this point official debates within the international community, did not manage to agree on a single strategy. As assessed elsewhere, "[i]f one consequence of international diplomacy over the past decade has been to radicalize the Kosovar Albanians, another has been to embolden Milošević or, at the very least, not to discourage him." 18 The frequent disputes and confrontations between the Serbian troops and the militarist KLA culminated in January 1999 when Serbian military forces massacred more than forty Albanians in the village of Račak, in central Kosovo. ${ }^{19}$ At this point, there was a clear transatlantic ambition to prevent the Serbian leadership from completing a strategy of ethnic cleansing and achieving full control of the territory. According to Joschka

\footnotetext{
${ }^{15}$ United Nations, "UN Security Council resolution 1160," 31 March 1998 (S/RES/1160).

${ }^{16}$ Fehim Rexhepi, "Echoes of the Milosevic-Yeltsin Meeting," AIM Priština, 18 June 1998, http://www.aimpress.ch/dyn/trae/archive/data/199806/80621-003-trae-pri.htm.

${ }^{17}$ Duma, "Russia: Duma Call for a Peaceful Solution to Kosovo Crisis," AP Archive, 14 October 1998.

${ }^{18}$ Richard Caplan, "International Diplomacy and the Crisis in Kosovo," International Affairs 74, no. 4 (1998): 745-61, 752.

${ }^{19}$ For the description of the Račak massacre as a crime against humanity, see Robert Bideleux and Ian Jeffries, The Balkans: A Post-Communist History (Oxon: Routledge, 2007), 542; Eric Gordy, Guilt, Responsibility and Denial: The Past at Stake in Post-Milošević Serbia (Philadelphia, PA: University of Pennsylvania Press, 2013), 7; Dino Kritsiotis, "The Kosovo Crisis and NATO's Application of Armed Force against the Federal Republic of Yugoslavia," International and Comparative Law Quarterly 49, no. 2 (2000): 330-59. Still, it should be noted that some prominent skeptics have questioned the whole Račak case (including the number of victims), going as far as to suggest that it was a hoax, much needed to trigger the later intervention. See Diana Johnstone, Fools' Crusade: Yugoslavia, NATO and Western Delusions (London: Pluto Press, 2002), 240-3.
} 
Fischer, the then German Foreign Minister, acting politely with Belgrade officials would lead only to more mass graves, so he stated that the use of force should be taken into consideration: "I am not a friend of using force, but sometimes it is a necessary means of last resort ... If people are being massacred, you cannot mutter about having no mandate. You must act." 20

Russia, even though it condemned the Račak tragedy and supported an immediate investigation, continued to side with the Serbian authorities. ${ }^{21}$ As witnessed by Levitin, the Russian side "agreed that Belgrade and Priština, together with the Contact Group, should negotiate a mutually acceptable new legal status for Kosovo," but simultaneously "[it] was constantly looking for reasons to cast a shadow on the Kosovar delegation, calling it 'illegitimate', its composition inappropriate, and raising the issue of the terrorist character of the KLA representatives." 22 Soon after, during the Rambouillet conference on the situation in Kosovo, its representatives made it clear that any NATO involvement would be interpreted as an act going against Russia's interests and that an attack on Serbia would be powerful enough to generate a "Vietnam in the Balkans." ${ }^{23}$ Interestingly, at Rambouillet, the Yugoslav and Kosovo Albanian representatives managed to agree on almost every aspect listed in the agreement, including the presence of an international force. However, the annex specifying the Status of Multi-National Military Implementation Force - meaning that NATO would exercise a full control of $\mathrm{Kosovo}^{24}$ - was made available to negotiators at the very last moment and, even worse, not given to the Russian team. In his attempt to trace back the sudden exclusion of Russia, although it was a crucial player in the period preceding and during the Rambouillet conference, Robin Blackburn writes that this actually happened because of the Americans, as they were the ones believing that the intervention would be more successful and that the Serbian regime would sooner give up if there was no Russian involvement. ${ }^{25}$ Still, even though the decision to exclude Russia was not without opponents among NATO officials, they nevertheless sided with the dominant US and British view, "sending out pathetic little signals of concern as the military juggernaut headed for the abyss" - a rigorous approach that was only reconsidered when the very NATO Secretary General Javier Solana stated that "'Russia must be on board' if the West was to tackle the critical issue of Kosovo," explaining that "Russia should be involved both because that would maximize the chances of a successful settlement and because to leave Russia out

\footnotetext{
${ }^{20}$ Fischer cited in Ivo H. Daalder and Michael E. O'Hanlon, Winning Ugly: NATO's War to Save Kosovo (Washington, DC: The Brookings Institution, 2000), 75.

${ }^{21}$ Monitor, "Russia Condemns Kosovo Massacre, but ...," 19 January 1999, http://www.jamestown.org/single/?tx_ttnews\%5Btt_news\%5D=15596\&tx_ttnews\%5BbackPid\%5D=2 13\&no_cache $=1 \#$. VFjHuSgvHRo.

${ }^{22}$ Levitin, "Inside Moscow's Kosovo Muddle," 137.

${ }^{23}$ Cited in Peter Schwarz, "Kosovo Peace Talks: The Failure of the Rambouillet Conference," 26 February 1999, http://www.wsws.org/en/articles/1999/02/kos-f26.html.

${ }^{24}$ Rambouillet Agreement, "Interim Agreement for Peace and Self-Government in Kosovo Rambouillet," 23 February 1999,

http://www.usip.org/sites/default/files/file/resources/collections/peace_agreements/kosovo_ramb.pdf. As rightly commented elsewhere, "[n]o government in the world would freely sign an agreement that amounted to giving away a rich province and accepting foreign military occupation, and Yugoslavia did not do so either" (Kees van Der Pijl, "From Gorbachev to Kosovo: Atlantic Rivalries and the Reincorporation of Eastern Europe," Review of International Political Economy 8, no. 2 (2001): 275-310, 299-300.

${ }^{25}$ Robin Blackburn, "Kosovo: The War of NATO Expansion," in Masters of the Universe? NATO's Balkan Crusade, ed. Tariq Ali (London: Verso, 2000), 360-80: 369.
} 
would be a colossal strategic snub." 26

However, with regard to Russia's position and options during the NATO-led air campaign against the FRY, Gabriel Gorodetsky is right when saying that the Kosovo crisis best outlined "both the aspirations and the constraints of Russian foreign policy;" while, on the one hand, it confirmed "the continued significance attached by Moscow to traditional interests, and particularly the predominance of the concept of spheres of influence," on the other, it exposed "the limits of Russia's capability for executing a more dynamic, resolute and independent policy." ${ }^{27}$ More precisely, the negative reaction to NATO bombing of Yugoslavia came from the country's political elites as well as from other sectors of Russian society, with some of their members labeling the aggression as "'barbaric', 'genocidal' and 'Hitlerite'." 28 Some representatives of the Russian Democratic Left, while strongly rejecting the socalled humanitarian aspect of NATO strikes and the idea that such an approach could help establish democracy, insisted on the economic and geopolitical reasons for the intervention, which represented "the beginning of a new epoch in world history - the beginning of the [western] recolonization of the world." ${ }^{29}$ Accordingly, "[s]ome MPs even went as far as to advocate a Union between Russia, Serbia and other Slavic nations, such as Belarus." ${ }^{~}$ From a different perspective, former and then members of the military - impossible to ignore due to the size of this electorate - kept expressing their anti-Western feelings and, in fact, became, even more, pro-nationalists, thus managing to secure additional influence in Russian foreign policy. Still, it is important to note that the above views were not without opposition. For example, Russian liberals and the general public, although aware of their country's national interests, did not fully discredit the West's intention to protect human rights violations in Kosovo. As summarized elsewhere, "[a]fter independent TV channels showed pictures of the suffering of Kosovo Albanian refugees, strong feelings began to subside," and this was exactly the point at which "[t]he section of the electorate committed to democracy, began to see that a pro-Serb and anti-American policy worked in favor of the communists." 31

As a matter of official protest, the Russian leadership declined the invitation to attend the $50^{\text {th }}$ anniversary NATO summit in Washington. Still, such a decision did not mean that Russia was going to do anything substantial, even though President Yeltsin had stipulated at the very beginning of the bombing that "[i]n the event that

\footnotetext{
${ }^{26}$ Ibid. In addition, for more analysis of Washington's ambitions, see Graeme Herd's “Europe and Russia: From Strategic Dissonance to Strategic Divorce," in European Security in a Global Context: Internal and External Dynamics, ed. Thierry Tardy (Oxon: Routledge, 2009), 93-112, and "Security Strategy: Sovereign Democracy and Great Power Aspirations," in The Politics of Security in Modern Russia, ed. Mark Galeotti (Farnham: Ashgate, 2010), 7-27.

${ }^{27}$ Gabriel Gorodetsky, "Introduction," in Russia between East and West: Russian Foreign Policy on the Threshold of the Twenty-first Century, ed. Gabriel Gorodetsky (London: Frank Cass, 2003), x-xx: xii. In addition, see Vladimir Baranovsky, "The Kosovo Factor in Russia's Foreign Policy", International Spectator 35, no. 2 (2000): 113-30.

${ }^{28}$ Astrid S. Tuminez, Russian Nationalism since 1856: Ideology and the Making of Foreign Policy (Lanham, MD: Rowman \& Littlefield, 2000), 280.

${ }^{29}$ Alexander V. Buzgalin, "Is NATO a Killer Cop? A View from the Russian Democratic Left," 1999, http://www.thing.net/ oliveworks/buzgalin.html.

${ }^{30}$ Christopher Williams and Zinaida T. Golenkova, "Russia: Walking the Tightrope," in The Kosovo Crisis: The Last America War in Europe?, eds. Anthony Weymouth and Stanley Henig (London: Pearson, 2001), 204-25: 212.

${ }^{31}$ Tom Gallagher, The Balkans in the New Millennium: In the Shadow of War and Peace (Oxon: Routledge, 2005), 70. In addition, see Tim Judah, Kosovo: War and Revenge (New Haven, CT: Yale University Press, 2002), 272-9.
} 
the military conflict worsens, Russia retains the right to take adequate measures, including military ones, to defend itself and the overall security of Europe." ${ }^{32}$ Even some Serbian politicians were rather skeptical about Russia's overall capability; according to Vuk Drašković, Yugoslav Deputy Prime Minister, "[ $\mathrm{t}]$ he people should be told that NATO is not facing a breakdown, that Russia will not help Yugoslavia militarily, and that world public opinion is against [the Serbs]." ${ }^{33}$ In contrast to the NATO summit, the Russian delegation did take part in a series of meetings that followed. For example, its presence at the June G8 Foreign Ministers meeting, held in Cologne, was of crucial relevance. At this point, Russian Foreign Minister Igor Ivanov - while aware of the importance of an earlier peace plan, presented by Martti Ahtisaari, President of Finland and an EU envoy, and Victor Chernomyrdin, Special Representative of the President of Russia, to President Milošević in Belgrade on 2 June 1999, and accepted by the Yugoslav authorities - assessed the proposed document: "This sort of document hardly ever satisfies those who take part in the negotiations. The important point is that this document should allow us to achieve the objectives that we had, which is to stop the war in the Balkans." 34

As the war came to an end, Russia decided to send troops to the Priština international airport on 12 June, occupying it before the arrival of the previously authorized NATO troops - a decision due to the marginal Russian presence within the new setting. ${ }^{35}$ Despite its peaceful outcome, this incident confirmed the Russian leadership's concerns about the future position of the Serbian population in Kosovo under the foreign supervision, but more importantly dilemmas about its own reputation at home and within the international system. When it comes to public opinion, even though the majority of Russians objected to the deployment of troops to Kosovo, they nevertheless believed that such presence was more relevant for Russia itself than the FRY, as it would boost Russia's international reputation. ${ }^{36}$ Thus, the Kosovo case managed to influence Russia's understanding of its own position and its relations with the rest of the world. The fact that NATO nevertheless decided to get involved militarily in the FRY - an approach strongly opposed by the Russians - was understood as a demonstration of "insulting disregard toward Russia" and intention to ostracize its participation in resolving some core European issues: "The air strikes against Yugoslavia, as viewed by Russia, were the most convincing justification for its negativity with respect to the prospect of establishing a NATO-centered Europe." ${ }^{37}$

\footnotetext{
${ }^{32}$ Yeltsin cited in CNN, "Yeltsin to Meet with Aides on Response to Bombings," 24 March 1999, http://www.cnn.com/WORLD/europe/9903/24/kosovo.reax.02/index.html. For more details about the position of the Yeltsin leadership during the Kosovo crisis, see Mark Smith, "Russian Policy during the Kosovo Conflict," in Britain, NATO and the Lessons of the Balkan Conflicts, 1991-1999, eds. Stephen Badsey and Paul Latawski (London: Frank Cass, 2004), 139-52.

${ }^{33}$ Drašković cited in Ian Jeffries, The Former Yugoslavia at the Turn of the Twenty-first Century: A Guide to the Economies in Transition (London: Routledge, 2002), 477. Similar views about the possibility of Russia's military involvement were presented by some other Serbian officials, including General Aleksandar Dimitrijević, Chief of Security Department of the Yugoslav Army; cited in Vladan Vlajković, Vojna tajna, I deo (Belgrade: Helsinški odbor za ljudska prava, 2004), 11.

${ }^{34}$ Ivanov's statements during "Press Conference: Secretary of State Madeleine K. Albright and Foreign Ministers, Following their Meeting, Cologne, Germany," 8 June 1999, http://www.library.utoronto.ca/g7/summit/1999koln/albright_june8.htm.

${ }^{35}$ Lajos F. Szászdi, Russian Civil-Military Relations and the Origins of the Second Chechen War (Lanham, MD: University Press of America, 2008), 190-9.

${ }^{36}$ Williams and Golenkova, "Russia," 218.

${ }^{37}$ Vladimir Baranovsky, "Russia: A Part of Europe or Apart from Europe?," International Affairs 76, no. 3 (2000): 443-58, 455. In addition, see Oksana Antonenko, "Russia, NATO and European Security after Kosovo," Survival 41, no. 4 (1999): 124-44.
} 
With this in mind, it was not difficult to foresee the continuation of standpoint differences between the West and Russia in the post-bombing period, now primarily focused on the future status of Kosovo.

\section{Russian post-1999 Consolidation of Relevance}

Once the 1999 NATO-led intervention had terminated, the UN Security Council Resolution 1244 established the UN Interim Administration Mission in Kosovo (UNMIK), exercising full executive, legislative and judicial role. The resolution declared the "establishment of an interim administration for Kosovo as a part of the international civil presence under which the people of Kosovo can enjoy substantial autonomy within the Federal Republic of Yugoslavia, to be decided by the Security Council of the United Nations. The interim administration was to provide transitional administration while establishing and overseeing the development of provisional democratic self-governing institutions to ensure conditions for a peaceful and normal life for all inhabitants in Kosovo." 38

The meetings accompanying Resolution 1244 were expected to clarify the position of external powers in the handling of the newly faced situation. For example, on 16 June, US Defense Secretary William Cohen talked to his Russian counterpart Defense Minister Igor Sergeyev in Helsinki; at this point, he insisted that Russia had to meet NATO's requirements: "[W]e made it very clear there cannot be a separate sector for Russia. So we are trying to find ways in which we can meet their needs, but not in any way violate the fundamental rules that NATO has to insist upon." 39 A few days later, in Brussels, NATO delivered a statement clarifying that it "look[ed] forward to the participation of the Russian Federation in KFOR [NATO-led Kosovo Force] within a unified chain of command" and that it "remain[ed] ready to resume consultations and full cooperation in the framework of the NATO-Russia Founding Act." ${ }^{40}$ Finally, at the G8 summit in Cologne, in the period 18-20 June, the leaders jointly expressed appreciation for Resolution 1244 and the efforts invested by the concerned parties. As the joint statement put it, the international community perceived the safe and systematic return of refugees and displaced persons as well as the provision of protection and security for all the minority groups as its high priorities priorities that expected steady commitment and belief of the residents of Kosovo that working together would help create a truly democratic and multi-ethnic Kosovo. ${ }^{41}$ However, the allocation of international supervisory duties that was put in place and expected to be able to deal with the above mentioned issues would later become a matter of serious concern and harsh criticism, mostly due to the precarious position of local Serbs. As James Hughes has correctly put it, "NATO's insistence on a marginal Russian military presence undoubtedly contributed to the ethnic cleansing of Serbs from Kosovo, as a stronger Russian contingent would have been more productive than

\footnotetext{
${ }^{38}$ United Nations, "UN Security Council resolution 1244," 10 June 1999 (S/RES/1244).

${ }^{39}$ Cohen cited in CNN, "Cohen in Helsinki for Talks with Russians over Kosovo Force," 16 June 1999, http://www.cnn.com/WORLD/europe/9906/16/kosovo.01/.

${ }^{40}$ NATO, “The Situation in and around Kosovo," 18 June 1999, http://www.nato.int/docu/pr/1999/p99097e.htm.

${ }^{41}$ G8, “Cologne Summit: G8 Statement on Regional Issues,” 20 June 1999, http://www.g8.fr/evian/english/navigation/g8_documents/archives_from_previous_summits/cologne_s ummit_-_1999/g8_statement_on_regional_issues.html.
} 
NATO forces in defending Serb areas." ${ }^{42}$

By looking at the position of the European Union, it saw the region impoverished and in need of substantial assistance. It persuaded the international community to collaborate in the Stability Pact for South Eastern Europe, adopted in Cologne. More precisely, the Brussels administration was concerned with the still-inpower Milošević regime, the provision of support to anti-Milošević Democratic Opposition of Serbia (which eventually overthrew him, in early October 2000), and the fragile and highly unpredictable situation in the post-intervention Kosovo. The Russian position, although challenged by the country's marginal involvement in the post-conflict NATO-dominated context, continued to confirm the previously offered arguments about the overall wrongdoing of the West in the Kosovo case. Vladimir Putin, soon after being elected President of Russia, in March 2000, approved the document Foreign Policy Concept of the Russian Federation, which among other interests and priorities, stipulated that Russia was ready to give "an all-out assistance to the attainment of a just settlement of the situation in the Balkans, one based on the coordinated decisions of the world community." 43 Accordingly, the settlement outcome implied preservation of the territorial integrity of the Federal Republic of Yugoslavia and, thus, strictly opposed any idea of partitioning of the state, as such a move would run the risk of "emergence of a pan-Balkan conflict with unpredictable consequences." 44 Moreover, given the critical moment at which it was produced after the bombing, but with Milošević still in office, this document warned that any idea about straightforwardness of the process dealing with the status of Kosovo, which would result in independence, but at the same time requiring Russian input, was a pure misunderstanding. Here, apart from being interested in defending the very idea about territorial integrity, quite some Russian representatives believed that Russia stood a fair chance to consolidate its global influence by (1) insisting on something that bore significant ethical considerations regardless of the region and (2) trying to discredit the European Union as such, but also its individual members for supporting the NATO intervention. In their view, the so-called aggressors (even if not convinced about the pursued polices) had to do everything in order provide Kosovo with independent status, which would in return ensure us that their approach was right and the only one. ${ }^{45}$

In Serbia, following the overthrow of Milošević, the country's new president Vojislav Koštunica, although aware of the importance of integrations in the European Union, still openly expressed appreciation for the Russian approach. His Democratic Party of Serbia's nationalist-conservative discourse insisted that the status of Kosovo should dominate the country's foreign policy. As argued, the pressuring Western approach to address the Kosovo question - meaning to grant it full independence at some point - had an alternative in Serbia's closer relations with Russia. During his

\footnotetext{
${ }^{42}$ Hughes, "Russia and the Secession of Kosovo," 1005. For additional proofs and analyses of the ethnic cleansing of Serbs, see Anthony Cleland Welch, "Achieving Human Security after Intra-State Conflict: The Lessons of Kosovo," Journal of Contemporary European Studies 14, no. 2 (2006): 22139; Human Rights Watch, Abuses against Serbs and Roma in the New Kosovo, Document 11, no. 10(D) (1999), https://www.hrw.org/reports/1999/kosov2/; Heike Krieger (ed.), The Kosovo Conflict and International Law, Cambridge: Cambridge University Press, 2001; Branislav Radeljić, "European Union Approaches to Human Rights Violations in Kosovo before and after Independence," Journal of Contemporary Central and Eastern Europe 24, no. 2 (2016): 131-48.

${ }^{43}$ Russian Federation, "The Foreign Policy Concept of the Russian Federation," 28 June 2000, http://www.bits.de/EURA/eura10.html.

44 Ibid.

${ }^{45}$ Interview with a former Russian official.
} 
visit to Moscow in late October 2000, Koštunica welcomed Russia's interest in the region, stating that " $[\mathrm{t}]$ he Russian presence must be felt in all the intersecting strategic geopolitical influences in the Balkans," so that a greater balance of European, Russian and US forces can be achieved. ${ }^{46}$ In return, some months later, Putin visited Belgrade, reconfirming Russia's support for the territorial integrity of Serbia. Regardless of what the real reasons behind Putin's first visit might have really been, ${ }^{47}$ in addition to Belgrade, he went to Priština to visit Russian peacekeeping forces and to speak to UN officials, insisting on a more obvious commitment of the international community to Resolution 1244. ${ }^{48}$ Subsequently, his 2003 decision to withdraw Russian troops from Kosovo was due to the fact that "the presence of [Russian] military contingent, which does not decide anything and cannot influence anything, was pointless," and not because Moscow had become "indifferent." 49

Aware of the problems and in order to find a durable solution, the international community welcomed the 'standards before status' approach, inaugurated by the third UNMIK chief, Michael Steiner of Germany, in 2003. ${ }^{50}$ Although the 'standards before status' policy covered a variety of issues, ranging from the establishment of democratic institutions and rule of law to the development of market economy and dialogue with Belgrade authorities, its essence "was that it required Kosovo's institutions of self-government to demonstrate that they were willing and able to protect the rights of all of Kosovo's ethnic communities, and had the capacity to act in a civilized way." 51 While the international community seemed to be enthusiastic about the Kosovo Albanian capabilities to address the expressed concerns, Russian and Serbian leaderships were rather relaxed, seeing the proindependence parties as too optimistic. In fact, Belgrade and Moscow believed that the promoted policy (in combination with the sections related to Serbian territorial sovereignty under Resolution 1244) served their ambition to discredit the validity of the status talk or, at least, to put it on hold. In addition, given the complexity of the situation, in which both the Serbian and Kosovo Albanian representatives approached the Kosovo question by having a plan A in mind only, according to which one party would end up as an absolute winner whereas the other would be an absolute loser, the 'standards before status' policy provided a brief moment for policy reconsiderations amongst some Western officials. ${ }^{52}$

However, the advocacy of 'standards before status' was fully eroded and, in fact, abandoned after the riots in mid-March 2004, involving more than 50,000 ethnic

\footnotetext{
${ }^{46}$ Koštunica cited in Smith, "Russian Policy during the Kosovo Conflict," 148.

${ }^{47}$ For example, Janusz Bugajski talks about three reasons: "First, Russia wanted to assert itself as a significant decision maker despite its economic weakness. Second, the Kremlin sought to demonstrate that although Central Europe had largely slipped from its grasp and the Baltics were heading toward NATO membership, the Balkans remained contested territory. And third, Putin's visit to Belgrade was intended to cement the alliance against threats to Yugoslavia's survival" (Janusz Bugajski, Cold Peace: Russia's New Imperialism (Westport, CT: Praeger Publishers, 2004), 172).

${ }^{48} \mathrm{See}$, for example, Michael Bothe and Boris Kondoch (eds), International Peacekeeping: The Yearbook of International Peace Operations, Vol. 7 (The Hague: Kluwer Law International, 2002), C 103.

${ }^{49}$ Putin cited in Milan Milenković, "The Kosovo Case as a Matryoshka Doll: Why Did Russia

Withdraw its Troops from Kosovo?,” South Slav Journal 31, nos. 3-4 (2012): 18-32, 27.

${ }^{50}$ Branislav Radeljić, "Official Discrepancies: Kosovo Independence and Western European Rhetoric," Perspectives on European Politics and Society 15, no. 4 (2014): 431-44.

${ }^{51}$ Arta Ante, State Building and Development: Two Sides of the Same Coin? Exploring the Case of Kosovo (Hamburg: Disserta Verlag, 2010), 150.

${ }^{52}$ Interview with a former Russian official.
} 
Albanian extremists that gathered to attack Serbs and Roma. ${ }^{53}$ In the newly established grey zone, the Standards Implementation Plan was introduced, placing a particular focus on the economy, rule of law and dialogue between Belgrade and Priština. Thus, the international community, while positioned between the two opposing sides, understood that any substantial progress with regard to human rights could not be made any time soon, but also that lack of status and Kosovo's security were affecting the entire Balkan region. As one 2004 analysis correctly put it, following the termination of the 1999 war, the international community continuously grappled with the Kosovo dilemma, suggesting that although Kosovo's status was absolutely crucial for a durable solution and stability of the Balkans, tackling the status question in itself undoubtedly represented a risk to stability: "If the international community tackles the status issue without adequate preparation, deadlock at best and confrontation at worst might be the result. If it waited for too long the unstable elements on the ground, in particular the impatience of the Kosovar population, the persistent economic crisis and the still tense relations between the ethnic communities might well lead to a new crisis." 54

The late 2005 Vienna talks were launched with an aim to resolve the final status of Kosovo. Led by UN Special Envoy Martti Ahtisaari and involving members of the Contact Group, the talks were expected to find the solution within Resolution 1244, which - although protecting the sovereignty and territorial integrity of the FRY - at this point, could have been interpreted in two ways: "Either it applied to the interim period of UN administration or it applied beyond that, constraining options for a final status agreement on Kosovo." 55 However, once the Serbian and Kosovo Albanian representatives started travelling to Vienna, it did not take long to realize that all of them attended the rounds with a plan A only, suggesting that one side would have to give up and accommodate the other. For example, the January 2006 session, very much concerned with the question of decentralization as capable of providing mechanisms to protect the minorities, was a complete failure; as observed afterwards, "neither side had given an inch," meaning that "relief agencies are preparing for the least-bad option - another exodus of Serbs." ${ }^{56}$ In contrast to their Western counterparts, the Russians tried to make it clear that they would not support any outcome that would go against the Serbs. Even at one point during the process, while sensing the possibility of certain issues being ignored, the Ministry of Foreign Affairs of Russian Federation felt it necessary to restate Moscow's approach:

"A priority objective is to provide for practical application of standards with a view to ensuring respect for fundamental rights and freedoms of all ethnic groups in the region. We insist that the settlement

\footnotetext{
${ }^{53}$ For a detailed account of the riots, see Human Rights Watch, "Failure to Protect: Anti-Minority Violence in Kosovo," March 2004, 16(6D), http://www.hrw.org/reports/2004/kosovo0704/7.htm. In addition, see CARE International, What Difference Has Peace-building Made? A Study of the Effectiveness of Peace-building in Preventing Violence: Lessons Learned from the March 2004 Riots in Kosovo (Cambridge, MA: CDA-Collaborative Learning Projects, 2006).

${ }^{54}$ Stefan Lehne, "Has the 'Hour of Europe' Come to Last? The EU's Strategy for the Balkans," in The Western Balkans: Moving on, ed. Judy Batt (Paris: Institute for Security Studies, 2004), 111-24: 116.

${ }^{55}$ Marc Weller, "The Vienna Negotiations on the Final Status for Kosovo," International Affairs 84, no. 4 (2008): 659-81, 662. The same understanding of the text of Resolution 1244 can be found in Christopher J. Borgen, “Kosovo's Declaration of Independence: Self-Determination, Secession and Recognition," ASIL Insights, 29 February 2008,

http://www.asil.org/insights/volume/12/issue/2/kosovos-declaration-independence-self-determinationsecession-and.

56 Tom Hundley, “Wary Serbs Watch Deadlocked Talks on Kosovo's Independence," The Chicago

Tribune, 10 June 2006.
} 
process should evolve in strict compliance with Security Council resolution $1244 \ldots$ We consider it necessary that negotiations on the future status of Kosovo be preceded by a decision of the UN Security Council based on the results of the Council's review of the progress in the application of the standards ... It is a matter of principal importance to assume that the decision on Kosovo will be of a universal character. It will set a precedent. Any speculation about the uniqueness of the Kosovo case is just an attempt to circumvent international legal rules, which distracts from reality. What is worse is that attempts of that kind generate distrust of the international community as it creates an impression of double standards being applied to the settlement of crises in various regions worldwide and of rules being enforced arbitrarily, depending on each individual case." ${ }^{27}$

During the final round, held in March 2007, the Serbian leadership (clearly backed by the Russian government) rejected Ahtisaari's settlement recommendation as unacceptable. Following the failure of the Vienna talks, the Special Envoy produced a report elaborating on his views. He acknowledged that although "both parties have reaffirmed their categorical, diametrically opposed positions: Belgrade demands Kosovo's autonomy within Serbia, while Priština will accept nothing short of independence," there was a pressing urgency to resolve Kosovo's status. Accordingly, the Special Envoy, based on his conclusions that "[r]eintegration into Serbia is not a viable option" and that "[c]ontinued international administration is not sustainable," recommended the following: "Kosovo's status should be independence, supervised by the international community." "Later, the Contact Group supported the establishment of a Troika consisting of representatives of the EU, US and Russia, to continue with further negotiations on the future status of Kosovo, hoping to achieve a mutually acceptable solution. Different scenarios put forward - including the Serbian proposal for a loose integration model (inspired by the one of Hong Kong), according to which Kosovo would get more than autonomy, but less than independence, ${ }^{59}$ and the Kosovo Albanian proposal, promoting the Treaty of Friendship and Cooperation, according to which Kosovo and Serbia were two independent states ${ }^{60}$ - did not obtain approval of the other side. At the end of its mandate, the Troika produced a report in early December 2007, stating that even though the parties had stuck to their original positions, the Troika efforts nevertheless managed to persuade them to commit themselves "to refrain from actions that might jeopardize the security situation in Kosovo or elsewhere and not use violence, threats or intimidation." 61 The Serbian National Assembly, clearly concerned about the country's unfavorable position and possible Kosovo's unilateral declaration of independence [UDI], adopted a resolution on 26 December, "order[ing] the Serbian government that all international agreements which the Republic of Serbia signs, including the Stabilization and Association Agreement [with the EU], must be aimed at the preservation of Serbia's sovereignty

\footnotetext{
${ }^{57}$ The Ministry of Foreign Affairs of Russian Federation, "Position of Russia at the $61^{\text {st }}$ United Nations General Assembly," September 2006, http://www.mid.ru/bdomp/brp_4.nsf/e78a48070f128a7b43256999005bcbb3/d8fa85a26fca4ee4c32571e f00254b31!OpenDocument.

${ }^{58}$ United Nations Security Council, "Report of the Special Envoy of the Secretary-General on Kosovo’s Future Status,” 26 March 2007, S/2007/168.

${ }^{59}$ For more details, see The Economist, "Go Slow on Kosovo: The Path to Independence Looks Longer than it Did before," 3 October 2007, http://www.economist.com/node/9897720; Veronika Oleksyn, "Serbs Suggest Hong Kong Model for Kosovo," The Washington Post, 5 November 2007, http://www.washingtonpost.com/wp-dyn/content/article/2007/11/05/AR2007110501340_pf.html. ${ }^{60}$ For more details, see Henry H. Perritt, The Road to Independence for Kosovo: A Chronicle of the Ahtisaari Plan (Cambridge: Cambridge University Press, 2010), 201.

${ }^{61}$ United Nations Security Council, "Report of the European Union/United States/Russian Federation Troika on Kosovo," 4 December 2007, S/2007/723.
} 
and territorial integrity." 62

However, by the end of 2007, the status of Kosovo had not been resolved. Regardless of the possible interpretations of the text of Resolution 1244, the West was keen on finding a durable solution and its rhetoric very often suggested that an attainment of independence was the desired outcome. ${ }^{63}$ Such an outcome was crucial not only for the Kosovo Albanian population, as they would get their own state, but also for the West itself as it would help justify the need for the 1999 NATO military intervention. On the other hand, the Serbian political establishment, although some of its members tied to promote a narrative that Kosovo was de facto independent and that both parties' representatives had to focus on the processes of democratization and Europeanization, the majority (aware of the importance of public support in order to preserve of their own status), continued to insist that Kosovo was and, most relevantly, would always be a constituent part of the Republic of Serbia - an approach backed by the Russian authorities whenever possible. The Kosovo Albanians, while understanding the divisions characterizing external rhetoric as capable of prolonging stagnation in terms of the Kosovo final status, decided to make a move themselves, hoping for international approval and recognition.

\section{Russia and Kosovo's Proclamation of Independence}

In February 2008, the Kosovo Albanian leadership adopted a resolution, proclaiming independence from the Republic of Serbia. ${ }^{64}$ With regard to European Union and its Member States position, the response was far from the one witnessed on 15 January 1992, when both the then European Community and its twelve members recognized Slovenia and Croatia as independent states, and thus terminated the existence of the Yugoslav federation. This time, due to the overall context, a session entitled Developments as Regards the Future Status of Kosovo, hosted by the Parliamentary Assembly of the Council of Europe, before Kosovo's proclamation of independence, clearly warned of possible divisions and their implications: "It is still in question whether the EU will manage to speak with one single voice in the case of UDI [Unilateral Declaration of Independence]; while some member states are prepared to recognize a UDI - including key countries such as the United Kingdom, France, Germany and Italy - a few others continue to express their hesitation at the prospect. The risk that, in the end, the decision on whether to recognize an independent Kosovo might be left individually to EU member states is not to be excluded." ${ }^{\prime 25}$ Across the EU, apart from five of its members (Cyprus, Greece, Romania, Slovakia and Spain) that decided not to recognize the newly self-proclaimed Republic of Kosovo, the others rushed to do so.

The position of the Russian Federation was in stark contrast to the one adopted by the dominant Western powers. Its Ministry of Foreign Affairs reacted immediately,

\footnotetext{
${ }^{62}$ For the full text of the resolution, see B92, "Serbian Parliament's Kosovo Resolution," 27 December 2014, www.b92.net/eng/insight/strategies.php?yyyy=2007\&mm=12\&nav_id=46517.

${ }^{63}$ Radeljić, "Official Discrepancies."

${ }^{64}$ For an analysis of the Kosovo Constitution, see Joseph Marko, "The New Kosovo Constitution in a Regional Comparative Perspective," Review of Central and East European Law 33, no. 4 (2008): 437 50, Martina Spernbauer, EU Peacebuilding in Kosovo and Afghanistan: Legality and Accountability (Leiden: Brill, 2014), 47-83, and Judge John Tunheim, "Rule of Law and the Kosovo Constitution," Minnesota Journal of International Law 18, no. 2 (2009): 371-79.

${ }^{65}$ Council of Europe, Documents Working Papers: 2008 Ordinary Session (First Part), 21-25 January 2008, Vol. 2 (Strasbourg: Council of Europe Publishing, 2008), 57.
} 
stating that the UDI "violat[ed] the sovereignty of the Republic of Serbia, the Charter of the United Nations, UNSCR 1244, the principles of the Helsinki Final Act, Kosovo's Constitutional Framework and the high-level Contact Group accords," and warning the international community of "the risk of an escalation of tension and interethnic violence in the province and of new conflict in the Balkans." ${ }^{66}$ Similar massages were delivered by individual statesman, ranging from Putin, for whom "[t]he precedent of Kosovo is a terrible precedent, which will de facto blow apart the whole system of international relations," ${ }^{67}$ to Russia's next president Dmitry Medvedev, who after his visit to Belgrade, when he supported Serbia's determination to fight against Kosovo's independence, ${ }^{68}$ went as far as to state that "[f]or the EU, Kosovo is almost what Iraq is to the United States, [being] the latest example of the undermining of international law." 69

The Russian rhetoric in the immediate post-UDI period turned out to be relevant for all the concerned sides. While the Serbs perceived it as extremely favorable for their own position, the Kosovo Albanians as well as the Brussels administration continued to feel challenged. A new round of official visits and statements very well illustrated the trend in place. For example, in mid-April 2009, the Russian Federation submitted a forty-page statement to the International Court of Justice (previously approached by the UN General Assembly with a request for advisory opinion as to whether the UDI was in accordance with international law), outlining its arguments in order to conclude that "the unilateral declaration of independence by the Provisional Institutions of Self-Government of Kosovo is not in accordance with international law." 70 In May, while welcoming a new ambassador from Serbia to Russia, Medvedev stressed: "We intend to continue to coordinate our foreign policy moves in future, including the ones related to the solving of the issue with Kosovo."71 Soon after, this approach was additionally clarified; in an interview to the Belgrade daily Večernje novosti, Russian Ambassador to Serbia Aleksandr Konuzin stated that "Russia's stand is rather simple - we are ready to back whatever position Serbia takes," but also made clear that "the EU is not an alternative to relations with Russia." "72 Instead, the ambassador explained that even Russia itself was keen on consolidating its relations with the EU, given the economic and political links, and therefore it was necessary "to find forms of cooperation between Serbia, Russia and the EU that would be beneficial to all three sides." "73 Still, it was

\footnotetext{
${ }^{66}$ The Ministry of Foreign Affairs of the Russian Federation, "Statement by Russia's Ministry of Foreign Affairs on Kosovo," 17 February 2008, http://www.mid.ru/bdomp/brp_4.nsf/e78a48070f128a7b43256999005bcbb3/041c5af46913d38ac32573 f30027b380! OpenDocument.

${ }^{67}$ The Sunday Morning Herald, "Putin Calls Kosovo Independence 'Terrible Precedent'," 23 February 2008.

${ }^{68}$ Aljazeera, "Medvedev Pledges Support for Serbia: Candidate Likely to be Russia's Next President Vows to Fight Kosovo Independence," 25 February 2008, http://www.aljazeera.com/news/europe/2008/02/2008525124618498728.html.

${ }^{69}$ ABC News, "Russia's Medvedev Condemns Western 'Paternalism'," 15 July 2008, http://www.abc.net.au/news/2008-07-16/russias-medvedev-condemns-westernpaternalism/439974? section=world.

${ }^{70}$ International Court of Justice, "Written Statement by the Russian Federation," 16 April 2009, http://www.icj-cij.org/docket/files/141/15628.pdf.

${ }^{71}$ Sofia News Agency, “Medvedev: Serbia Is Russia’s Key Partner in Southeast Europe,” 29 May 2009, http://www.novinite.com/view_news.php?id=104112.

72 Večernje Novosti, “Ambassador Underlines Russian Backing,” 12 June 2009, http://www.b92.net/eng/news/politics-article.php?yyyy=2009\&mm=06\&dd=12\&nav_id=59780. 73 Ibid.
} 
Medvedev's visit to Belgrade in October 2009 that offered a clearer picture about Russian intentions and long-term involvement in the region. In his analysis, Aleksandar Fatić rightly observes that " $[\mathrm{t}]$ he visit marked a sharp turn..., with the new and more assertive rhetoric suggesting Russia's willingness to engage in 'infighting' the Western military and energy security interests." 74 For both Medvedev and Konuzin, it was important to assure the Serbs that "Kosovo echoes in the hearts of all Russians with the same pain as it does in your hearts." 75 In terms of further clarification of the Russian position, it did not take long before Konuzin decided that it was needed to warn the Serbian authorities that their country could not join NATO and count on endless Russian support - a standpoint expected to send a signal that NATO membership would affect the previously promised support. ${ }^{76}$ Later, when Putin visited Serbia in March 2011 (thus after the publication of the advisory opinion of the International Court of Justice stipulating that Kosovo's UDI was in accordance with international law ${ }^{77}$ ), in addition to confirming Russia's willingness to support its South Slavic brothers in energy and financial spheres, he also stated that Russia would support Serbia's Kosovo policy, observing that it was "not necessary to elaborate on the reasons for this, as they are deeply rooted in the two countries' long history of relations and their closeness." 78

Following the 2012 elections in Serbia, Putin congratulated the newly elected President Tomislav Nikolić, the founder and first president of the Serbian Progressive Party, who had underlined that Serbia needed to focus on new opportunities (including cooperation with all countries in the world as well as EU membership) and less on alternatives (usually implying the choice between the West and Russia), while Kosovo was seen as an autonomous province of Serbia, not independent - an approach generally welcomed by the voters, especially the ones who were not entirely convinced about their last-minute decision to give vote to Nikolić, a former Radical, and not to the former President, Boris Tadic of the Democratic Party. ${ }^{79}$ The Russian leader kept insisting on friendship and mutually beneficial cooperation - links that are in the interest of the two countries as well as Europe as a whole. ${ }^{80}$ The exchange of words of support between the two presidents encouraged various assessments in the West. Some EU officials noted that Serbia was "at a crossroads;" Nikolić's victory "proved that the country's political landscape had become more complex and that the EU needs to be involved in an intensive dialogue with Serbian authorities and all political leaders from the very first moment." ${ }^{\text {"1 }}$ At home, while the panic surrounding

\footnotetext{
${ }^{74}$ Aleksandar Fatić, “A Strategy Based on Doubt: Russia Courts Southeast Europe,” Contemporary Security Policy 31, no. 3 (2010): 441-64, 441.

${ }^{75}$ Fonet, "Russian Envoy: Kosovo in Russia’s Heart," 29 November 2009, http://www.b92.net/eng/news/politics-article.php?yyyy=2009\&mm=11\&dd=29\&nav_id=63375.

${ }^{76}$ B92, "Serbia Can't Have both NATO and Kosovo," 5 February 2010, http://www.b92.net/eng/news/politics.php?yyyy=2010\&mm=02\&dd=05\&nav_id=65001.

${ }^{77}$ International Court of Justice, "Accordance with International Law of the Unilateral Declaration of Independence in Respect of Kosovo (Request for Advisory Opinion),” 22 July 2010.

${ }^{78}$ B92, "Putin: Russia Remains Serbia’s Ally," 23 March 2011, http://www.b92.net/eng/news/politics.php?yyyy=2011\&mm=03\&dd=23\&nav_id=73400.

${ }^{79}$ Blic, "Ko kome može da uzme birače," 19 April 2012, http://www.blic.rs/Vesti/Politika/317966/Kokome-moze-da-uzme-birace; CeSID, "Konačna procena mandata," 7 May 2012; Reuters, "Serbians Vote for President under Threat of Protest," 20 May 2012, http://www.reuters.com/article/2012/05/20/us-serbia-election-idUSBRE84J04G20120520.

${ }^{80}$ Tanjug, "Putin Congratulates Nikolić on Being Elected," 21 May 2012, http://www.tanjug.rs/news/44009/putin-congratulates-nikolic-on-being-elected.htm\#. ${ }^{81}$ Miroslav Lajčák, "Serbia Faces Historic Turning Point," EUobserver, 29 May 2012, http://euobserver.com/opinion/116401.
} 
government formation was going on, ${ }^{82}$ the newly elected president decided to pay his first visit abroad, to Russia. Although informal in official terms, this visit opened numerous questions about the politics of alternatives and whether the new Serbian leadership, contrary to the electoral campaign, was going to minimize its links with the West and move more towards the East. As reported, in Moscow, Russian president Putin started his welcome note by wishing Nikolic "to implement everything that was stated in [his] election program and to fulfill the Serbian people's expectations," that economic cooperation between the two "increased by almost $50 \%$ in the past year" and that Russians "see Serbs as [their] spiritual brothers." 83

Indeed, given the worrying economic situation at home (the average salary at around $€ 300$ and the youth unemployment rate at more than 40\%), the Serbian leadership had to explore opportunities that would eventually improve the living standard of the citizens of Serbia. As Russia's deputy prime minister Dmitry Rogozin stated during his visit to Serbia, "[t]he difference between the EU's and Russia's approach is that Russia has the desire and money to invest in Serbia" and also underlined, something that is of crucial importance to pro-European forces, that " $[t]$ here is no conflict of interest between Serbia's EU membership and friendship with Russia." 84 For example, the South Stream project, first presented as something truly crucial but then cancelled, ${ }^{85}$ was seen as a big step forward: by having the pipeline passing through its territory, Serbia would be getting cheaper gas and Russia would secure access to a bigger European market and confirm its influence in European Union affairs given that the $21^{\text {st }}$ century is often described as the century of energy politics. Additionally, a strong Serbian-Russian economic partnership could also lead to a strong political partnership, an upgrade that is surely facilitated by Nikolić's clear announcement in Moscow that "Serbia will never become a member of NATO." 86

However, Russian military intervention in Ukraine and the consequent annexation of Crimea in March 2014 encouraged numerous questions about similarities between the cases of Kosovo and Crimea and the contradictions and inconsistencies characterizing Russia's approach towards the notion of territorial integrity. As assessed by Michael Ignatieff, "Putin is serving up a series of international law justifications that are periodic versions of some of the ones he didn't like in the 1990s." ${ }^{87}$ Still, as Putin explained it, "[Russia's] western partners created the Kosovo precedent with their own hands. In a situation absolutely the same as the one in Crimea they recognized Kosovo's secession from Serbia legitimate while arguing that no permission from a country's central authority for a unilateral declaration of independence is necessary." 88 While discussing the West's position visà-vis Kosovo - with the former insisting on the latter be treated as a unique case -

\footnotetext{
${ }^{82}$ Vreme, "Koalicioni pregovori: Pravilo trojno srpske politike," no. 1117, 31 May 2012, http://www.vreme.com/cms/view.php?id=1055239\&print=yes.

${ }^{83}$ Kremlin, "Meeting with Serbian President-elect Tomislav Nikolić," 26 May 2012, http://eng.kremlin.ru/transcripts/3914.

${ }^{84}$ Tanjug, "Rogozin: Russia is with Serbia," 28 November 2012, http://www.tanjug.rs/news/67723/rogozin--russia-is-with-serbia.htm.

${ }^{85}$ Tim Boersma, "The Cancellation of South Stream is a Pyrrhic Victory, at Best," 18 December 2014, http://www.brookings.edu/blogs/up-front/posts/2014/12/18-south-stream-pipeline-boersma.

${ }^{86} R T$, "Serbia Says "Nyet" to NATO Membership," 28 May 2012, http://rt.com/politics/serbia-russianato-eu-crisis-377/.

${ }^{87}$ Michael Ignatieff, "Is the Age of Intervention Over?," Chatam House, 19 March 2014, http://www.chathamhouse.org/events/view/197401.

${ }^{88} R T$, "Putin: Crimea Similar to Kosovo, West Is Rewriting its own Rule Book," 18 March 2014, http://rt.com/news/putin-address-parliament-crimea-562/.
} 
Putin observed that such an approach is "beyond double standards ... It's a kind of baffling, primitive and blatant cynicism. One can't just twist things to fit his interests, to call something white on one day and black on the next one." 89

In the West, as expected, Russian official rhetoric and adopted policies were analyzed and heavily criticized. ${ }^{90}$ More precisely, for US President Barack Obama comparing Crimea with Kosovo was pointless: "When I hear analogies to Kosovo, where you had thousands of people who were being slaughtered by their government, it's a comparison that makes absolutely no sense." 91 In a similar way, German Chancellor Angela Merkel described the comparison as "shameful," clarifying that the Kosovo crisis was characterized by "years in which the international community had no power to intervene, while Slobodan Milošević carried out his ethnic cleansing," and only when it became clear that the status quo was not tolerable any longer, "NATO then decided to act alone because Russia continuously blocked any UN mandate on Serbia." 92 Some scholars went on to claim that, if a parallel should be drawn, it should be between Crimea and Croatia (whose authorities autonomously held a referendum on independence, in May 1991), not Kosovo. ${ }^{93}$ The Kosovo Albanian authorities understandably showed appreciation for such clear-cut perceptions, clearly reflecting their own interests. In an interview to Reuters, Kosovo's Prime Minister Hashim Thaci insisted that "[u]nder no circumstances can the Kosovo case be compared with the case of Crimea. Kosovo is a unique case. The international community intervened after the genocide by Serbia took place ... We never demanded to leave one country and join another." 94 In the neighboring Albania, the official line has supported such a view; as observed by Prime Minister Edi Rama, Putin's comparison made no sense whatsoever. ${ }^{95}$

Since the beginning of the Ukrainian crisis, the Serbian leadership has tried to adopt a neutral position, which would show respect toward Russia, but also be acceptable for the Brussels administration, so that Serbia's integration in the

\footnotetext{
${ }^{89}$ Ibid.

${ }^{90}$ See, for example, Bahri Cani, "Interview with Franz-Lothar Altmann - You Can't Compare Crimea and Kosovo," Deutsche Welle, 12 March 2014, http://www.dw.de/you-cant-compare-crimea-andkosovo/a-17493034, Daniel W. Drezner, “Putin's Excuse for a Referendum is Wrong: Crimea Isn't Kosovo - at all," The Guardian, 17 March 2014, http://www.theguardian.com/commentisfree/2014/mar/17/putin-referendum-crimea-kosovo, Paul Linden-Retek and Evan Brewer, "Why Crimea is not Kosovo, and Why It Matters," Open Democracy, 18 March 2014, https://www.opendemocracy.net/od-russia/paul-linden-retek-evan-brewer/Crimeajustified-kosovo-ruling-icj-2008-russia-putin, David L. Phillips, "Crimea Is not Kosovo," The Huffington Post, 10 May 2014, http://www.huffingtonpost.com/david-1-phillips/crimea-is-notkosovo_b_4936365.html, and Ilya Somin, "Why the Kosovo 'Precedent' Does Not Justify Russia's Annexation of Crimea," The Washington Post, 24 March 2014, http://www.washingtonpost.com/news/volokh-conspiracy/wp/2014/03/24/crimea-kosovo-and-falsemoral-equivalency/.

${ }^{91}$ BalkanInsight, "Crimea-Kosovo Analogy Nonsense, Obama Says,” 26 March 2014, http://www.balkaninsight.com/en/article/crimea-kosovo-analogy-nonsense-obama-says.

92 Valentina Pop, "Merkel: Comparing Crimea to Kosovo Is 'Shameful'," EUobserver, 13 March 2014, https://euobserver.com/foreign/123454.

${ }^{93}$ Cornelia Navari, “Territoriality, Self-Determination and Crimea after Badinter," International Affairs 90, no. 6 (2014): 1299-1318, 1315.

${ }^{94}$ Fatos Bytyci, "Don't Use our Case to Justify Crimea, Kosovo PM Tells Russia," Reuters, 27 March

2014, http://www.reuters.com/article/2014/03/27/us-ukraine-crisis-kosovoidUSBREA2Q14V20140327.

${ }^{95}$ BalkanWeb, "Rama dhe Ponta kundër Putin: Rasti i Krimea nuk ngjason me Kosovën," 19 March 2014, http://www.arkivalajmeve.com/Rama-dhe-Ponta-kunder-Putin-Rastii-Krimea-nuk-ngjason-meKosoven.1047545603/.
} 
European Union would not be compromised. In his study about Serbia's position, Filip Ejdus has suggested that its neutrality should not be understood "as purely rational and interest-driven." In fact, Serbia's behavior was very much due to "an existing tension between two powerful collective identity narratives in Serbia" - one which is about belonging to Europe (the EU and the West more generally) and the other which is about Orthodox brotherhood with Russia; accordingly, while "[u]nable to change either its identity or its behavior, Serbia resorted to avoidance, a defensive mechanism used by actors who seek to reduce an identity conflict by selective exposure to information and denial of the dissonance." ${ }^{96}$ However, at the official level, while trying to defend his country's standpoint, Prime Minister Aleksandar Vučić said that "[w]e support the territorial integrity of every country, including Ukraine. But, let's put it this way, I asked that Serbia, for the sake of traditional ties ... maintain its position and not introduce sanctions against Russia." ${ }^{97}$ Soon after, Serbian Foreign Minister Ivica Dačić confirmed that "Serbia will never work against Russia, that it is a question of morality, and that Serbia and Russia will continue their mutual projects." 98 Furthermore, the presence of Serbian volunteers helping proRussian forces in Crimea - a support strongly inspired by the shared Orthodox faith, Russia's advocacy in the case of Kosovo and, more generally, anti-Western views ${ }^{99}$ encouraged a range of thoughts about the balancing aspect and thus Serbia's overall direction.

To begin with, it is important to note that since 2007, the volume of contacts, prospects for cooperation and promises exchanged between Serbia and Russia has remarkably increased. ${ }^{100}$ At the same time, the pro-EU sentiment in Serbia has decreased. ${ }^{101}$ Still, according to some observers, the former should not be the reason for the latter; as pointed out by Sonja Biserko, head of the Helsinki Committee for Human Rights in Serbia, "without Russia's involvement and without its support in certain informal centers, Serbia would not be in the situation in which it unfortunately finds itself today," blaming the Serbian elite for being naïve to believe that "it is in Russia's interest to support Serbia. It is a naïve way of looking at the world, bound up with the provincialism that imbues our perception of the world and what is happening around us." 102 Indeed, the Crimean question has revealed that Russia was ready to ignore its previous advocacy of territorial integrity and pursue its own geopolitical interest by assisting Ukraine's disintegration. Going further, with the election of a new Serbian government in 2012, the country was once again exposed to the question of alternatives and speculations (Russia or the European Union and, most likely, NATO membership), but this time the situation seemed rather different, as the new government presented itself as fully aware both of the existing uncertainties and, more

\footnotetext{
${ }^{96}$ Filip Ejdus, "Beyond National Interests: Identity Conflict and Serbia's Neutrality toward the Crisis in Ukraine," Südosteuropa, vol. 62, no. 3 (2014): 348-62, 349.

${ }^{97}$ Vučić cited in Maja Poznatov, "Serbia's Careful Balancing Act on Ukraine," EurActiv, 9 May 2014, http://www.euractiv.com/sections/enlargement/serbias-careful-balancing-act-ukraine-302018.

${ }^{98}$ Dačić cited in Poznatov, "Serbia's Careful Balancing Act on Ukraine."

${ }^{99}$ See, for example, Marija Ristić, "Serbian Fighters Help 'Russian Brothers' in Crimea," BIRN, 6

March 2014, http://www.balkaninsight.com/en/article/serbian-fighters-head-to-crimea, and Aleksandar Vasović, "Serbian Paramilitaries Join pro-Russian Forces in Crimea," Reuters, 14 March 2014, http://www.reuters.com/article/2014/03/14/us-crimea-volunteers-idUSBREA2D0C020140314.

${ }^{100}$ See, for example, Žarko N. Petrović (ed), Russia-Serbia Relations at the Beginning of XXI Century (Belgrade: ISAC Fund, 2010).

${ }^{101}$ Ioannis Armakolas and Maja Maksimović, “The Risk of Losing Serbia," EurActive, 6 December 2012, http://www.euractiv.com/enlargement/risk-losing-serbia-analysis-516493.

${ }^{102}$ Sonja Biserko, "Serbia's Alternatives," Radio Slobodna Evropa, 12 December 2011.
} 
importantly for its own reputation, Serbia's opportunities. With this in mind, there was not much space left for the politics of alternatives. The Progressivists-dominated leadership decided to focus on potential benefits, regardless of the provider. Surely, it would have been problematic to present the Russian federation as an alternative, economically or ideologically. Economically, the EU is Serbia's biggest trade partner. Ideologically, although Titoist Yugoslavia was often proud of its similarity to the Soviet Union, the present-day Serbs are trying to be closer to the EU and the West in general rather than the Russians. Some recent research has revealed that Serbs are less interested in studying Russian than English, that they find western culture much more attractive than Russian one, and very relevantly, the ones who decide to emigrate looking for better living conditions do not really opt for Russia, but some other, more economically and politically stable countries. ${ }^{103}$ In the end, the signature of the EUbrokered April 2013 Agreement between Belgrade and Prištna - assessed as "a landmark deal" by the Brussels administration, ${ }^{104}$ "the best possible offer" by Ivica Dačić, ${ }^{105}$ "a first and historic agreement between Serbia and Kosovo" by Hashim Thaci, ${ }^{106}$ has provided space for policy reconsiderations and suggested that Serbia has to focus on political adjustments and durable solutions, which imply good neighborhood relationships. ${ }^{107}$ In this respect, Serbia has entered a rather difficult phase, which should result in providing Kosovo with its already long-awaited status. Aware of the new developments, the Russian overall position has not significantly changed; in a lecture given at the Belgrade Academy for Diplomacy and Security, the Russian Ambassador in Belgrade Alexander Chepurin stated that his country does not object to Serbia's accession to the EU per se. However, taking about NATO membership, in the ambassador's view, it would be "utter stupidity if somebody from Serbia were to crawl over and beg (to join), after the bombing that incurred Serbia damages worth USD 120 billion ... That's the red line that in no way suits Russia. NATO was created against the Soviet Union, which is long gone, and it is absolutely unclear what NATO stands against now - or do you really want to go to war in Iraq, Libya, or Syria?" 108

Vladimir Putin visited Belgrade in October 2014. At this occasion, previously announced as "destined to be success," "109 he expressed appreciation for Russia-Serbia relations: "Russia, just as in the past, will always see Serbia as our closest ally." "As a response, he was assured that "Serbia also sees Russia as its big ally and Serbia will

\footnotetext{
103 Jelena Milić, “The Russification of Serbia,” New Eastern Europe 13, no. 4 (2014): 94-102, 95.

${ }^{104}$ European Union, "Serbia and Kosovo Reach Landmark Deal,” 19 April 2013, http://eeas.europa.eu/top_stories/2013/190413_eu-facilitated_dialogue_en.htm.

105 Politika, "Dačić: Najbolja ponuda dosad, medjunarodno priznat sever," 20 April 2013, http://www.politika.rs/rubrike/tema-dana/Dacic-Ocekujem-konsenzus-o-ponudi-iz-Brisela.lt.html. ${ }^{106}$ Deutsche Welle, "Majorities in Kosovo, Serbia Support New Deal," 20 April 2013, http://www.dw.de/majorities-in-kosovo-serbia-support-new-deal/a-16759798.

${ }^{107}$ For a detailed analysis of the agreement, see Adem Beha, "Disputes over the 15-Point Agreement on Normalization of Relations between Kosovo and Serbia," Nationalities Papers 43, no. 1 (2015): 102-21.

${ }^{108}$ Chepurin cited in $B 92$ (Beta/Tanjug), "Serbia's NATO Membership: 'Red Line for Russia',' 27 November 2013, http://www.b92.net/eng/news/politics.php?yyyy=2013\&mm=11\&dd=27\&nav_id=88482.

${ }^{109}$ Chepurin cited in B92 (Beta/Tanjug), "Putin's Visit 'Destined to be Success'," 15 October 2014, http://www.b92.net/eng/news/politics.php?yyyy=2014\&mm=10\&dd=15\&nav_id=91909.

${ }^{110}$ Putin cited in $B B C$, "Putin Guest of Honor at Serbia Military Parade," 16 October 2014, http://www.bbc.co.uk/news/world-europe-29641642.
} 
not jeopardize its moral principles due to some negative attitudes towards Russia." 111 By this point, Ukraine had already been subjected to various stages of Russian intervention, leading to the EU's decision to introduce sanctions against Moscow. ${ }^{112}$ Therefore, the fact that the Serbian leadership, which was expected to adopt a firm stance vis-à-vis the intervention and side with the Brussels administration, did not respond positively to EU authorities, apart from being interpreted as Belgrade's ambition to balance and therefore secure economic and political benefits from both sides (as a part of the EU membership negotiation process and access to Russia's natural resources), could also be understood as a provision for an even greater presence and relevance of Moscow in Balkan and EU affairs. In fact, the recent visits of Aleksey Pushkov, the head of the Foreign Affairs Committee in the Russian Duma, for whom joining the EU does not anymore mean prosperity and well-being (as it used to for some Central and Eastern European countries), ${ }^{113}$ and Dmitry Rogozin, who has, in contrast to his 2012 rhetoric, adopted a more skeptical view about EU accession (stating that the Brussels administration is actually much worse that the Soviet regime), ${ }^{114}$ are persuasive efforts suggesting what kind of direction should Serbia should pursue.

\section{Conclusion}

The 1999 Kosovo crisis has encouraged a whole range of dilemmas and questions (some answered and some, hopefully, to be answered), including the one about Russia's involvement. In contrast to the period before the Yugoslav state crisis of the early 1990s, when there was no obvious Soviet interest in Kosovo as an autonomous province of Serbia, the post-Yugoslav period has witnessed an increased engagement of Moscow. This started with the attendance of inauguration of the Federal Republic of Yugoslavia in 1992, continued throughout the decade by taking part in numerous meetings and official statements, and culminated with the Kosovo war and the consequent discussions about its final status. Writing about the post-1999 period, one author suggested that Russia's presence in the region "should implicitly be considered the country's most significant regional interest. Such a presence could be regarded as necessary in order not to let the developments in the area be controlled completely by other international actors. Also, a Russian presence seems to be both acceptable and desirable to regional and external actors as an important balancing element. The Balkans, in this line of thinking, might represent the only area outside the territory of the former USSR in which Russia has a chance to achieve results that are not available to other external actors." 115 Clearly disappointed with the NATO-led intervention and its marginal role, the Kremlin insisted on the territorial integrity of

\footnotetext{
${ }^{111}$ Serbian President Tomislav Nikolić cited in $B B C$, "Putin Guest of Honor." In addition, see Radio Free Europe, "Putin Vows To Support Serbia On Kosovo," 16 October 2014, http://www.rferl.org/content/russia-serbia-putin-us-criticism-belgrade/26640165.html.

112 European Union, "EU Restrictive Measures," Factsheet, 29 April 2014. For more details, see European Union, "EU Sanctions against Russia over Ukraine Crisis,” EU Newsroom, http://europa.eu/newsroom/highlights/special-coverage/eu_sanctions/index_en.htm.

${ }^{113}$ Bojan Bilbija, “Aleksej Puškov: Srbija je za Putina prioritetna država,” Politika, 31 October 2015, http://www.politika.rs/scc/clanak/342494/Srbija-je-za-Putina-prioritetna-drzava.

${ }^{114}$ Blic, "Packe Rogozina: Kako je ruski vicepremijer gurnuo ‘prst u oko' zvaničnom Beoradu," 14 January 2016, http://www.blic.rs/vesti/politika/packe-rogozina-kako-je-ruski-vicepremijer-gurnuo-prstu-oko-zvanicnom-beogradu/q2k0b73.

${ }^{115}$ Baranovsky, "The Kosovo Factor," 128.
} 
the Republic of Serbia. As expected, the 2008 declaration of independence of Kosovo as simply was unacceptable in every respect. For the majority of Serbs this proved as vital in their attempt to preserve Kosovo, regardless of the signals coming from the West, including the advisory opinion of the International Court of Justice.

However, Moscow's policy of amity and cooperation with Belgrade did not only serve the case of the Serbian representatives in front of the international community, but also the case of the Russian leadership, hoping to strengthen its own position in EU and world politics more broadly. As Andrew Konitzer correctly observed in 2010, 'Russia's 'defense' of Kosovo bought critical time for Serbia to mount a diplomatic offensive which has contributed to the current impasse over the province's future status while avoiding head-on confrontation with major Western actors," but then, when thinking about long-term prospects, should Serbia's accession to NATO take place, "the web of interests which currently complements Russia and Serbia's 'historical friendship' will transform into mutually exclusive choices which will either destroy the Russian-Serbian partnership or undermine Serbia's prospects for EU membership." 116 Since then, while Serbia has managed to secure a full EU candidate status (2012) and signed the so-called Brussels agreement with Kosovo (2013), Russia attacked and violated the sovereignty of Ukraine - an action that opened numerous questions about Moscow's Kosovo-related argument insisting on the preservation of territorial integrity of Serbia. In her attempt to criticize the Kremlin, Chancellor Merkel assessed that "Russia is not acting like a stability partner, but uses its neighbor's weakness to advance its own interests. It is the power of the mightiest put above the power of law. What we are witnessing now is oppressive." 117 The notion of weakness is also important when considering Russian penetration in Serbia, welcomed by President Nikolić when proudly stating in Moscow " $t]$ he only thing I love more than Russia, is Serbia" 118 as well as by the Serbian Orthodox Church. As one study of the 'Russification' of Serbia has summarized the trend, "[o]rganized or spontaneous coordination of Serbian and Russian interests, both those publically and behind closed doors (not necessarily state level, but also private) resulted in a specific linkage of significant groups and individuals and the creation of the so-called 'Putin's orchestra' in Serbia. Its members are placed in all strategic institutions: within the cabinets of Vučić and President Nikolić, in business, the energy sector and security agencies. There are also members in NGOs, cultural organizations, the academic community, sport and media. There is more and more evidence that some members of 'Putin's orchestra' are financed directly from Moscow." 119

With the above-outlined concerns in mind, it is possible to conclude that Russia has undoubtedly managed to secure its place in EU-Western Balkan relations and therefore become extremely important for the Brussels administration that is expected to identify the most appropriate strategy for Serbia, but also other Western Balkan countries, such as Macedonia, Montenegro, and Bosnia and Herzegovina. Still, what should not be forgotten and, in fact, often matters more than the views

\footnotetext{
${ }^{116}$ Andrew Konitzer, "Serbia between East and West: Bratstvo, Balancing, and Business on Europe's Frontier,” NCEEER Working Paper, 2010, http://www.ucis.pitt.edu/nceeer/2010_824-

22t_Konitzer.pdf.

${ }^{117}$ Valentina Pop, "Merkel: Comparing Crimea to Kosovo Is 'Shameful'."

${ }^{118}$ Nikolić cited in The Economist, "To Russia with Love,” 18 September 2012, http://www.economist.com/blogs/easternapproaches/2012/09/russia-and-serbia.

119 Jelena Milić, "The Russification of Serbia," 98. According to the author, one of the signals suggesting that "the activities of the Putin orchestra in Serbia have brought fruit" is the noticeable drop of support for EU membership (99).
} 
expressed by Russian or any other external actor, is incapability of the local authorities and peoples to come up with a durable solution (in the case of Kosovo, regarding its status, human rights protection, fight against corruption, institutional capacity building and so on), even though various initiatives and EU summits have tried to communicate a message that the future of both Kosovo and Serbia lies within the EU. ${ }^{120}$ However, in the embedded confrontational relationship, individual external actors - less concerned with the progress of Kosovo, but more with their own standing - have understood their involvement as an opportunity, geoeconomic or geopolitical.

${ }^{120}$ See, for example, Štefan Füle, “Boosting Serbia’s and Kosovo’s European Future,” 15 January 2013, http://europa.eu/rapid/press-release_SPEECH-14-29_en.htm. 